\title{
The Theme of Loss and Grief in Shashi Deshpande's Small Remedies
}

\author{
Vanitha Devaraju \\ Guest Lecturer \\ Arignar Anna Government Arts College \\ Villupuram, Tamil Nadu, India \\ vanithadevaraju@gmail.com
}

\begin{abstract}
A writer throws light on the darkest aspects of life and motivates the reader by projecting the human realities through their fictional characters. Success and failure are the part of impermanent life. Have we ever tried to analyze the struggles and challenges behind one's failure and success? In a patriarchal society, women have to undergo multiple struggles and challenges and require an indomitable spirit to quench her thirst of success. It is highly important to analyze the psychology of women in her loses and happiness. As a woman novelist, Shashi Deshpande novels mostly centered on Women's lives and their challenges to survive in the Indian society. The female protagonist in Small Remedies has gone through several loses and grief beyond her success. Other women characters also built their strong identity after crossing all the barriers and awakening the collective consciousness.
\end{abstract}

Keywords: Patriarchy, Gender discrimination, Resistance, Identity.

Introduction

The present research paper intends to study women's life, their loses and grief beyond their success and identity with the reference to Shashi Deshpande's Small Remedies. The 
characters in the novel are facing heavy loss and grief beyond their success and identity. This could be seen in the three important women characters Madhu, Savitri Bai and Leela. In reality, human builds a strong personal identity after facing several struggles, sufferings, agony, several loses and grief. Although they win in the end, one can't deny that they haven't had any loses in their past. Especially for women, it takes long time to reach the top and she has to cross through the barriers to reach. Shashi Deshpande novels represent the ultimate epitome of women's grief behind the success.

Shashi Deshpande portrays the women characters to endure intolerable sufferings to survive. They always lived with a hope for the future. Throughout their lives, women have faced a series of disappointments along with humiliation, torture and repeated displacement. Small Remedies is a novel revolving around three women characters with different life and career.

When novel proceeds, we could see the most beloved persons are leaving out the world. The novel starts as Madhu travels to Bhavanipur to meet Savitri Bai. Madhu thought to write a biography of Savitri Bai, in her last year. Actually, Madhu lost his son Aditya, in order to recover from her son's death, Madhu was asked to write a book on a biography of Savitri Bai. She interviewed Savitri Bai. As the novel gradually proceeds, Madhu from her memory she is drawing out and shares the stories of Leela, Savitri Bai and Munni. Madhu tries to make sense of these women's life in doing so, she hopes to find a way of her own despair. The three women characters Leela, Savitri Bai and Madhu have faced their own loss and grief in life. Madhu as a narrator narrates the life of the other two women. However, Madhu finds her own identity by introspecting herself.

\section{$\underline{\text { Savitri Bai : }}$}


Savitri Bai obsessed with the music. She had a successful career. Through her life, we could know that gross gender discrimination prevails in the field of classical music as well. When Savitri Bai wished to play the tabla, her grandfather refused it. Girls were restricted from playing musical instruments. Savitri Bai's struggles were expressed in this novel: " How much longer it takes for a woman to reach the top, how difficult it is for her to break through the barrier to get there."(224) She had to face many struggles to come up in her life. She gained popularity and reputation in her music profession but not in her personal life. When Madhu was asked to present Savitri Bai's biography as a heroine, she refused to write. Instead, Madhu reflected her as daring independent nature that makes to seek her own identity and elope with a Muslim the tabla player. Savitri Bai had a sheltered life in her childhood and also as a daughter- in -law in a Brahmin family. Later, there were several gossips about her personal than career life. She was hurt when the grandmother asked her to stop singing immediately in her family gathering scenario.

Savitri Bai didn't express and reveal about her personal life which had pain and grief. It is unclear about Munni and her relationship with mother. However, as a reader, one could understand how much pain and struggles she would have faced attaining her identity as 'singer'. It is not easy for an Indian woman in 1980's to come up on the stage. If someone is really famous in the media, her virtue was tested. Savitri Bai deserves to be appreciated for her talent and guts. Gender discrimination in a society exactly puts the female down in spite of her dedicated hard work and talent. She was neither allowed to choose her life partner nor career. Savitri Bai had been highly criticized by the society and family for eloping with her lover a Muslim - tabla player that disturbed her psychologically.

Savitri Bai left all her family, child, husband and other relationship in order to succeed in her career. She had a successful career yet failed in her personal life. On seeing her student Haasina's performance, Savitri had tears as it reflected her past personal life. 
Our society was so conditioned as to categorize women as immoral and slightest deviation in their past from the normal course of behavior (Amarnath, Vol.2 ). Madhu realizes that for a man( her father) was acceptable for the way they live by breaking the conventional rules indulging themselves in drinking alcohol and having immoral conduct. Even Savitri Bai's grandfather breaks the orthodoxy. Women should not live her life on her own. Through this novel, Shashi Deshpande expressed the lack of female's identity and freedom but culturally man has: "Being a man he could get away with much; He could live the way he wanted to without open censure or disapproval."(139) Society plays an important role in assigning women rules and roles. In our Indian society, each family had its place marked out for it according to religion, caste, money and family background (Jasbir Jain). Society and its dimensions on women had greatly impacted the lives of Savitri Bai, Madhu and Leela. Imposing certain rules and customs will make their condition worsen. It added fuel and the grief more.

Although Leela was a widower, she has been criticized for having the second marriage with Joe; Savitri Bai was also criticized for elopement. Savitri Bai attained huge famous in singing but lost respectability as a woman in the society. This could be firmly seen in Madhu's words: "In Neemagon, she was 'the singer woman' and there was something derogatory about the words, Yes I can see that now about the way they said them."(29) Savitri Bai had to endure great mental torture as she was treated like an untouchable among woman. However, her father-in-law never discouraged her from singing. The little freedom she enjoyed was a great cause for contempt and jealousy towards other women and they would throw caustic remarks on her way back from her music classes ( Amarnath Vol.2). The stress and torturous experience that Bai has undergone is revealed in the following lines: "But the subtle cruelty of persistent hostility leaves deeper wounds. There is always the 
temptation to succumb, to be back to the normal path and be accepted. To resist the temptation speaks of great courage."(221)

The society has spoiled her reputation and brought disgrace to Savitri Bai's life by criticizing for her private life. She expressed " A woman who had left her husband's home considered as an immoral woman." (222) Savitri Bai has faced severe trauma and misery out of insults, humiliation and rejection. She was secluded and all alone now. only her student Haasni helps her now. However, as a singer Savitri Bai withholds her identity in the society.

Leela:

Leela, another important female character who also faces several loses and grief in her life. There was no one in her family to encourage and support. Her mother opposed Leela in attaining education. She was married to Vasanth in the tenth standard itself. Her dreams of education were shattered. Vasanth supported her initially. However, she could not perceive her dreams after Vasanth's death. Her life gets worse day by day. She had to face all the struggles as a widow. She took up a job and supported the family by educating her brother in - law. She had to live in the crowded crawls among the cotton mills. She worked for the welfare of the poor women suffering from the contagious disease T.B. During this met, she married Joe, a Doctor. Leela and Joe's relationship was strong despite quite differences in their likes and dislikes. Their happiness didn't prolong, her struggle and grief continued again after the death of Dr. Joe due to a massive heart attack.

Her struggles and challenges extended as she involved herself in communist ideology and politics. Despite her hard work, she hasn't been recognized. As a widower, Leela wasn't allowed to represent in the election. Leela reverberates: " It seems you have to become a widow for them to remember that you exist."(224) She went to the jail for the welfare of the public strike that she involved in it. Unlike Savitri Bai, she left her own dreams, education 
desires for the purpose of the family. At last, she also died. However, from the beginning to end she has been portrayed as Madhu's aunt who guides Madhu. Leela epitomized as courage woman. Madhu proudly acclaims that Leela was ahead not only of her generation but the next one as well.

Leela, a widower and social reformist in the political side gave higher challenges and pain. She lost her husband which added grief and sufferings more. Despite all struggles, she was projected as a warrior and reformer and won hearts of the people.

\section{Madhu:}

Madhu, a protagonist of the novel, struggles throughout her life and pinned with grief from childhood to adult. Since childhood, she was motherless and felt the longing for that. Her father accompanied and has taken care of her. She was brought up with two male company, his father and servant Bala. After the sudden death of her beloved father, Madhu started to stand by her own. Her friends, Joe and Leela supported Madhu to overcome. she faced much crisis and loses side by side. As she grows, problems in her life also increased. When joined an office in Bombay, she was tortured to Dalvis sexual harassment. She felt lonely and her mind suffered more. Her marriage relationship was happy for some time until the death of her son Aditi. Madhu was disturbed by her nightmares. She was pinned in grief and desperate when she innocently reveals about the relationship with a man at the age of fifteen. When she exposed Chandru's abuse, her husband Som reacted as " Tell me the truth, tell me the truth.(258) The suspicion of husband and her son Aditi's death shattered her mind. She was psychologically depressed and disturbed with nightmares. She didn't believe that her son was dead. She always had a hope that Aditi would back home. She confronts and understands the reality only at the end of the novel. 
Husband's suspicion at wife reveals the general psychology of man. This suspicion made the pair to depart. The desperate and painful state of Madhu expressed as:

" In my despair, I think of tearing off my clothes and saying to him: look, look at this. This is the woman you pursued and married, this is the body you slept with and enjoyed all these years. If you think that truth lies in this body if you imagine that the truth is what this body has done, look carefully at it." (256)

Madhu as a woman groans against the gender issues and sexual harassments. She realized the fact that being a woman, she had to face lots of struggles and disturbances. Madhu express, "It is impossible for a young woman to be unnoticed. Native won't allow it. It doesn't suit her purpose."(161) When Madhu was young, she had been attracted, noticed and abused. She faced many problems in her life for being a woman. The same woman, in her last ages turns invisible to the society. Invisibility comes to a woman when she is old.

Madhu as soon as hears death, there is a grief in her heart which expressed more and more. First, she lost her father, then Joe, Leela and later his own son Aditi. In the end, she is waiting for the death of Savitri Bai. However, her heart was ready to face her death boldly. This could be observed when she had a talk with Latha that she has no fear of death. Savitri Bai and Leela was internally hurt and had emotional disturbances. Madhu's fate, one by one relationship was moving away and leaving her soul tearing into grief and despair. However, Madhu makes her mind strong and would come out of her son's death by writing the biography of Savitri Bai. Madhu introspect herself by recollecting her past memories. She is determined to recover from her loses and pain.

Thus Shashi Deshpande's Small Remedies raises several issues related to feminist perceptions, gender discrimination and the status of women in society. However, the theme of loss and grief is suitable to all the characters in Small Remedies as well as applicable in reality. Once a man is born, definitely he has to face the death. Everyone has to deal life with 
several relationships and emotions. The grief and happiness always co-exist in human life. The main characters in the novel Madhu, Savitri Bai and Leela achieved success in spite of several loses and grief in their lives. They identified themselves with their indomitable spirit. Shashi Deshpande projected them as the most beautiful people who have known defeat, sufferings, struggle, loss and finally they have found their way out of depths. 


\section{References}

Deshpande, Sashi. Small Remedies. Viking Publications: Indian Penguin Books,2000

Prasad, Amarnath. New lights on Indian women novelists in English- Part 2. New Delhi: Sarup and Sons Publication, 2004, pp 79 -100.

Jain, Jabir. Gender realities, human spaces: The Writing of Shashi Deshpande. Jaipur and New Delhi: Rawat Publication, 2003.

Naik K, Chanchala. Writing difference - The novels of Shashi Deshpande. Pen craft International Publication, 2005. 